\title{
ON LITTLE-KNOWN AND UNDESCRIBED EGGS FROM THE KUKU-NOOR.
}

\section{By ERNST HARTERT.}

THE following small collection was sent to this Musenm by Herr Taneré, whose collector had brought it together in the province of Amdo, only a little east of the Kuku-Noor, in the hills just south of the town of Si-ning.

All the eggs were accompanied by the parent birds in good skins, and carefully labelled with the corresponding numbers. I have named the birds myself.

\section{Merula kessleri Przew.}

Pleske, Aves, Przewalski's Reisen, pp. 21-28.

The eggs agree entirely with Pleske's excellent description and figures.

\section{Ruticilla rufiventris (Vieill.).}

Oates, in Hume's Nests and Eggs Ind. B., ii., p. 64 (1890); Pleske, Aves, Przewalski's Reisen, p. 56.

Clutches of four and five eggs sent. They are of a uniform sky-blue colour, paler than those of Ruticilla phoenicurus, a little larger than the usual size of the latter, and quite spotless. They measure $19 \cdot 6$ to $20 \cdot 5: 14 \cdot 7$ to $15 \cdot 4$.

Pleske (l.c.) also mentions the eggs, which are said to have fine, hardly perceptible, brown punctures on the broad end.

\section{Ruticilla frontalis (Vig.).}

Pleske, Aves, Przewalski's Reisen, pp. 65, 66, pl. v., fig. 5 ; Oates, in Hume's Nests and Eggs Ind. B., ii., p. 64.

Several clutches, containing five and six eggs each, are of a delicate greenish blue, with more or less indistinct small rufous brownish spots near the larger end, in some almost invisible, in a few others forming a very distinct and obvions ring. If held against the light they transpare delicate blne; they are elongate ovate, some more pointed towards the smaller end, moderately glossy. They measure

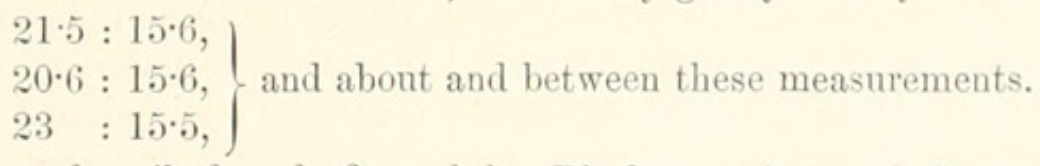

The eggs described and figured by Pleske as those of Rut. frontalis and R. schisticeps (l.c.) are entirely different from those described here, and I have considerable doubt whether they are any Ruticillue at all. All authenticated eggs of members of the genus Ruticilla are either bluish (the majority of the species), occasionally, though faintly, spotted, or white (R. tithys), and those in Mr. Rothschild's Musenm follow this rule. Therefore I rather believe our eggs to be the true eggs of $R$. frontalis than those found by Przewalski, and my opinion is backed by the eggs described as probably belonging to $R$. frontalis in Oates' book (l.c.), although 
unfortunately their identity is very donbtful. In concluding thus I am quite aware of the danger in generalising facts in oology, and I know that cases are well known where closely allied forms lay entirely different eggs-so Muscicapa grisola (eggs spotted) and $M$. atricapilla (eggs uniform blue), two birds which even by keen genera-splitting ornithologists (cf. for example the Catalogue of Birds, vol. iv.) are mostly placed into the same genus - but such cases are exceptional, and it is a most striking thing that in such cases similarly coloured species lay similarly coloured eggs, while slight so-called " structural " differences seem to have less influence on the eggs' colour. So the greyish striped M. grisola has the eggs spotted, while the black-andwhite $M$. atricapilla and $M$. collar is have similar blue eggs; so the black-and-white wagtails have all eggs of the well- known character of those of M. luctuosa and M. alba, while the yellow wagtails, the M. Alaxa and its many allies - which on account of a somewhat different hind-claw and different habits have been, wrongly, as Sharpe and I and many others think, generically separated as Budytes-have quite different eggs, and the also yellow M. sulfurea (melanope), which nobody included into Budytes, but which remained in the genus Motacilla, has eggs quite similar to those of the yellow "Budytes" group.

Again, cases of one and the same species laying eggs of totally different types and character are extremely exceptional, although the rule in Cisticola and allied forms, so that it would hardly be advisable to suppose that both Przewalski's and our eggs were true $R$. frontalis eggs. Pleske, it is true, also described two differently coloured eggs as those of $R$. frontalis, but they are not half so far from each other as his and ours. It is also only fair to mention that an allied bird, the Pratincola moussieri* of North-West Africa, also lays eggs of two different types; but in this case too they are not half so far one from another as those described as belonging to $R$. frontalis. While Salvin (Tbis, 1859, p. 307) and Canon Tristram (Ibis, 1859 , p. $416 ; 1860$, p. 365 ) only found eggs that were white with the faintest tinge of bluish green, Dr. A. Koenig recently (see Journ. f. Orn., 1892, p. 415, footnote) found them of two types-white with the faintest tinge of bluish green, and others of a light greenish blue colour.

\section{Chimarrhornis leucocephalus (Vig.).}

Oates, in Hume's Nests and Eggs Ind. B., ii., p. 63; Pleske, Aves, Przewalski's Reisen, pp. 6i-69.

One clutch of three eggs only sent. Pleske, althongh giving good details of the habits of this bird, does not describe the eggs, and also Oates seems only to repeat Hume's notes and did not see the eggs himself, so that it is doubtful whether there are any eggs of this bird in any European museum. Mr. Anderson, in Oates' book (l.c.), says that the eggs are so very like giant specimens of the eggs of Rhyacornis fuliginosus (Vig.) that any further description is almost superfluons. I have not those of Rhyacornis fuliginosus before me, but I find that the eggs of Chimarrhornis resemble the better marked ones of Pratincola caprata, which, according to Mr. Brooks, in Oates (l.c.), p. 65, are much like those of Rhyac. fuliginosus. However, I find that the eggs of Chimarrhornis leucocephalus are

* Although $P$. monssieri has been originally described as an Erithacus, and is often termed Ruticilla monssicri, so also in Dresser's Birds of Europe, all observers-Salvin (l.c.), Canon Tristram (l.c.), and Dr. Koenig (in his various articles in the Journ.f. Orn.) - state that it is more a Pratincola than a Redstart. and so says Seebohm (Cat. B., v., p. 406), and so should I conclude without hesitation from the bird' appearance. 
much more like those of Copsychus saularis and its allies, with which they can easily be mixed up. Indeed, in comparing ours with some of the latter, I, by mistake, put one of the Copsychus in the box with those of Chimarrhornis and in its place one of the latter, an error which I only discovered when measuring the Chimarrhornis clutch. Indeed, I believe that Chimarrhornis is most closely allied to the genera Cittocincla and Copsychus, which together shonld stand near to Ruticilla. This arrangement is already made by Oates in the Birds of India, and seems to be perfectly justified. It was no doubt a great mistake to exclude the "Copsychinae" from the Turdidae, as was formerly done by many, and some of the best ornithologists too.

The eggs of Chimarrhornis are ovate, a little more pointed than the majority of those of Copsychus (see Oates, l.c., p. 85), moderately glossy. The ground colour is a very pale green, blotched with different shades of reddish brown, more so near the larger end. They measure 24 to $24 \cdot 7: 17 \cdot 5$ to $17 \cdot 7 \mathrm{~mm}$.

\section{Phylloscopus affinis (Tick.).}

Herbivocula affinis Pleske, Aves, Przewalski's Reisen, p. 115.

One clutch of seven and one (apparently incomplete) of four eggs. The eggs of the former are very little glossy, ovate, white, spotted and speckled with pale brownish red, more so near the large end, forming an ill-defined zone. They are similar to many eggs of our Phylloscopus trockilus (L.). They measure $15 \cdot 6$ to 16 : $10 \cdot 7$ to $11 \mathrm{~mm}$.

The other clutch consists of four eggs, which are but short ovate, more glossy and white, with only very few tiny spots near the larger end. They measure $14 \cdot 9$ to $15: 11 \cdot 8$ to $12 \cdot 1 \mathrm{~mm}$.

Among the eggs of European Phylloscopi similar variations are common.

\section{Dumeticola thoracica Blyth.}

Dumeticola thoracica Blyth, Journ. As. Soc. Beng., xiv., p. 584 (1854-orig. descr.).

Lusciniola thoracica Seeb., Cat. B., v., p. 124, pl. 6.

Dumeticola affinis Hodgs. (thoracica Blyth), Taez., J.f. O., 1872, pp. 354, 355 (eggs !).

Dumeticola thoracica Pleske, Aves, Przewalski's Reisen, p. 123, pl. 5, fig. 7 (egg).

Tribura thoracica Oates, B. Brit. Ind, i., p. 365 ; id. in Hume's Nests and Eggs Ind. B., i., p. 229.

This bird has unfortnnately been placed into different genera, and I am not able to decide about its proper position before having gone into the question minntely. At present I have retained the first generic name under which it was described ; but this has to make place for Tribura if Tribura luteiventris is entirely congeneric. Perhaps Seebohm was after all right in placing it under Lusciniola, although one might remove some of the species which he united under this generic name in the Catalogue of Birds, vol. v.

One clutch of five eggs sent. The eggs agree with the former descriptions, being ovate, some short ovate, the shell fine, almost withont gloss. Ground colour white, speckled and spotted with brownish red and an underlying pale purplish red, much thicker round the larger end, where in some a ringlike zone is formed. They are considerably smaller than those found by Przewalski, but agree with the 
measurements given by Oates, and some given by Taczanowski, who recorded their great variability in size. Those before me measure $16 \cdot 6$ to $17 \cdot 2: 12 \cdot 5$ to $12 \cdot 9 \mathrm{~mm}$.

\section{Pterorhinus davidi Swinh.}

Pleske, Aves, Przewalski's Reisen, p. 134.

The eggs agree perfectly with the description of Pleske. They have quite the character of those of Garrulax pectoralis and monitiger, but are, of course, smaller. Clutches were found with five and six eggs.

\section{Anthus rosaceus Hodgs.}

Oates, in Hume's Nests and Eggs Ind. B., ii., p. 216.

Two clutches of four and five eggs respectively. They are of the well-known character of Anthus = eggs. The clutch of four is not unlike many eggs of Anthus arboreus, being of a greyish whitish ground colour, thickly freckled over the whole surface with brown and greyish brown, and measuring $20 \cdot 6: 16 \mathrm{~mm}$. The other clutch is different, with the ground colour lighter and more visible, the whole surface freckled and spotted with a pale earthy brown and greyish deeper-laying spots. Size of the eggs of this clutch, $21 \cdot 2: 15 \cdot 8 \mathrm{~mm}$.

\section{Motacilla leucopsis Gould.}

Clutches of five eggs. They are quite of the character of those of Motacilla alba Linn., and measure $20 \cdot 3: 16 \cdot 2$; a little larger in another clutch.

\section{Carpodacus pulcherrimus (Moore).}

Propasser pulcherrimus Oates, in Hume's Nests and Eggs Ind. B., ii., p. 153.

The exceedingly beantiful eggs are like the well-known eggs of Carpodacus erythrinus, but smaller, measuring only $19 \cdot 1$ to $19 \cdot 6: 14$ to $14 \cdot 3 \mathrm{~mm}$. They are of a pale clear blue. In some the spots on the larger end are very small and fine, and of a very dark, almost black, brown ; in others they are larger and almost deep purple brown, and in one they are long and fine hairlike lines and figures. The eggs are here described for the first time.

It is not worth while to separate the genera Propasser and Carpodacus, as Oates did in the Birds of India, and I follow Sharpe (Cat. B., xii.) in uniting them. The eggs, too, are quite of the same character.

\section{Carpodacus rubicilloides Przew.}

Przew., Rowley's Orn. Misc., ii., p. 299, pl. 54 (1877).

One clutch of three eggs. They have the beantiful pale blue colour so characteristic of the eggs of Carpodacus, and are marked with a few spots, specks, and hairlike lines of a deep purplish brown or almost black. They are larger than the eggs of C. erythrinus (Pall.) generally, but in East Prussia, where the eggs of this bird seem to be larger on an average than those from Northern Asia, I have found some that fully reach these in size, the eggs of $C$. rubicilloides measuring $21 \cdot 2,21 \cdot 4$, and $21 \cdot 6: 15 \cdot 3,15 \cdot 4$, and $15 \cdot 5$, while I took eggs of C. erythrimus in E. Prussia measuring up to $22 \mathrm{~mm}$. in length, althongh the majority is much smaller.

The one female sent with the eggs seems to belong to $C$. rubicilloides. I have no specimen to compare with it, but I do not think that the bird can belong to any 
other species, all the other allied species being before me. It is most similar to the female of C. grandis Blyth, but a little paler and the wing longer, the latter measuring fully 3.9 inches, which is even longer than that given by Przewalski.

\section{Acanthis brevirostris (Bp.).}

Oates, in Hume's Nests and Eggs Ind. B., ii., p. 155.

Quite like the eggs of Acanthis Aavirostris and cannabina, but a little smaller, measuring $17: 12 \cdot 4$ and $17 \cdot 1: 12 \cdot 6 \mathrm{~mm}$. Five and six in the clutch.

\section{Lanius tephronotus (Vig.).}

Oates, in Hume's Nests and Eggs Ind. B., i., p. 327 (1889).

Clutches of five eggs were found. They vary considerably, like other shrikes' eggs. Some clutches consist of eggs with a pale greenish white shell, others of such with a reddish buff shell, and the buff ones have reddish markings, the greenish ones deep brown spots and pale sepia grey clouds, all after the fashion of the eggs of Lanius collurio. In size they vary considerably too, and some clutches have a ringlike zone of spots near the thicker end, while in the reddish clutch the markings are scattered all over the eggs. In size they resemble those of Lanius rufus and its subspecies rutilans, or are larger and vary much, like the latter, in size and form.

\section{Podoces humilis Hume.}

Several clutches of five eggs were sent. It surprised me not a little to see these eggs, as they were pure white! They are ovate and elongate ovate or oval, moderately glossy, very smooth, and with several impressed lines along the surface, and not at all unlike the eggs of Iynx torquilla. If held against the light they shine throngh white, not at all yellow or greenish. They measure $21 \cdot 6: 16 \cdot 2$, $23 \cdot 5: 16 \cdot 0,22 \cdot 5: 16 \cdot 5$, and about and between these measurements, and the shell is rather hard.

I am well aware that in the Journal für Ornithologie, 1873, p. 63 and pl. 3, figs. 37, 38, the eggs of Podoces panderi Fischer were characterised as entirely different, coloured and spotted, and that later collectors proved the correctness of that description, and that it seems very remarkable that a bird of the same genus should have such different eggs; but I have no reason to doubt the correctness of these eggs of Podoces humilis. Herr Tancré's collector, Rückbeil, who is entirely to be trusted, according to Herr Taneré, sent the bird, and on its label the remark that the clutches numbered so-and-so belonged to it. Even if the collector had made a mistake with the first nest, he would probably have discovered his mistake later on. If we accept it as a fact that the white eggs of Podoces humilis are correct, it would seem a shock to the enthusiastic oologists' belief in the importance of oology in systematic questions, and I must admit that I hardly know of two other birds of the same genus having so totally different eggs. (See former remarks nnder Ruticilla frontalis, antea, p. 670.)

\section{Perdix sifanica Przew.}

A number of eggs are all alike, quite like those of Perdix perdix (L.), but the shell perhaps not quite so smooth. They have the well-known pale olive brown or milk-and-coffee colour of our partridges' eggs, are inside sea-green by transparent light, and measure 34 and $35: 23 \mathrm{~mm}$. 


\section{$2 \mathrm{BHL}$ Biodiversity Heritage Library}

1894. "On little-known and undescribed eggs from the Kakurnoor." Novitates zoologicae : a journal of zoology in connection with the Tring Museum 1, 669-673. https://doi.org/10.5962/bhl.part.24571.

View This Item Online: https://www.biodiversitylibrary.org/item/24179

DOI: https://doi.org/10.5962/bhl.part.24571

Permalink: https://www.biodiversitylibrary.org/partpdf/24571

\section{Holding Institution}

Natural History Museum Library, London

\section{Sponsored by}

Natural History Museum Library, London

\section{Copyright \& Reuse}

Copyright Status: Public domain. The BHL considers that this work is no longer under copyright protection.

This document was created from content at the Biodiversity Heritage Library, the world's largest open access digital library for biodiversity literature and archives. Visit BHL at https://www.biodiversitylibrary.org. 